\title{
Fertilizer Adoption and Use Intensity Among Smallholder Farmers in Northern Ghana: A Case Study of the AGRA Soil Health Project
}

\author{
Edward Martey ${ }^{1}$, Alexander Nimo Wiredu ${ }^{1,2}$, Prince M. Etwire ${ }^{1}$, Mathias Fosu ${ }^{1}$, S. S. J. Buah ${ }^{1}$, John Bidzakin ${ }^{1}$, \\ Benjamin D. K. Ahiabor ${ }^{1} \&$ Francis Kusi $^{1}$ \\ ${ }^{1}$ CSIR-Savanna Agricultural Research Institute (CSIR-SARI), Ghana, P.O. Box TL 52, Tamale, Ghana \\ ${ }^{2}$ Rural Development Theory and Policy, Institute of Agricultural Economics and Social Sciences in Tropics and \\ Subtropics, University of Hohenheim, Stuttgart, Germany \\ Correspondence: Edward Martey, CSIR-Savanna Agricultural Research Institute, Ghana, P.O. Box TL 52, \\ Tamale, Ghana. Tel: 233-242-344-450. E-mail:marteywayo2@yahoo.com; eddiemartey@gmail.com
}

Received: November 1, 2013 Accepted: December 15, 2013 Online Published: December 24, 2013

doi:10.5539/sar.v3n1p24 URL: http://dx.doi.org/10.5539/sar.v3n1p24

\begin{abstract}
Northern Ghana is characterized by food insecurity largely due to over reliance on rain-fed agriculture under low farm input conditions. The present study investigated the effect of factors influencing mineral fertilizer adoption and use intensity among smallholder farmers in Northern Ghana. A total of 330 smallholder farmers selected through multi-stage sampling technique were interviewed. Adoption of fertilizer technology was determined by age, nativity, farm size, access to credit, and distance to agricultural office. The result of the truncated regression estimates indicated that income of household head, membership of farmer association, distance to agricultural office, access to input shop, income earning household that do not participate in agricultural development project and income-earning male-headed household were the significant factors influencing fertilizer use intensity. Distance to agricultural office was a key positive determinant of fertilizer adoption and use intensity. The study recommends improvement in road infrastructure and technical training of agricultural extension agents. Farmer based organizations must be trained on regular basis to enhance their productive skills and technology uptake.
\end{abstract}

Keywords: fertilizer, adoption, soil health project, probit, truncated

\section{Introduction}

\subsection{Background and Problem Statement}

Agriculture in Ghana is predominantly on a smallholder basis. About $90 \%$ of farm holdings are less than two hectares in size, although there are some large farms and plantations, particularly for rubber, oil palm and coconut and to a lesser extent, rice, maize and pineapples (Chamberlin, 2007). The smallholder farmers are dispersed, and this makes provision of support services expensive and ineffective. Production is also largely rain-fed with limited mechanization and inadequate use of improved technologies such as high and stable yielding crop varieties, good agricultural practices, fertilizers, and other agro-inputs. These among many other things have contributed to the observed low levels of productivity in the agricultural sector (Chamberlin, 2007).

Cereals are major crops of importance to the agricultural sector of Ghana. Northern Ghana, which comprises Northern, Upper East and Upper West regions - accounts for over 40 percent of agricultural land in Ghana and is considered the breadbasket of the country (MoFA, 2010). The most important food crops in northern Ghana are maize, rice, sorghum, pearl millet, cassava, groundnut, cowpea and soybean. For most farm families, cereals are the most important staples. The importance of maize is demonstrated in its expansion to even the drier areas of northern Ghana where it has virtually replaced sorghum and millet which were traditional food security crops in the region. Northern Ghana produced about 350,000 metric tons of maize in 2011 over an area of 245,000 ha (SRID, MoFA, 2012). Nearly all production of cowpea (95\%) and soybean (97\%) in the country emanates from northern Ghana (SRID, MoFA, 2012).

The area is however inundated with high levels of food insecurity and poverty. Nearly one million people amounting to about half of the population of the area face annual food deficit and are net buyers of food (GSS, 2008) which is a major concern to the government and its development partners. About 80 percent of the population depends on subsistence agriculture with very low productivity and low farm income (MoFA, 2010). Per 
capita income of the area is about US\$200.0 per annum, which is less than 50 percent of Ghana's per capita income of approximately US $\$ 600.0$ per annum (GSS, 2008). The main reason for the extreme poverty and high food insecurity is the over reliance on rain-fed agriculture under low farm input conditions.

Low soil fertility has also been identified as a major contributor to the low yields recorded by the agricultural sector (MoFA, 2010). The soils of the major maize growing areas in northern Ghana in particular are low in organic carbon $(<1.5 \%)$, total nitrogen $(<0.2 \%)$, exchangeable potassium $(<100 \mathrm{ppm})$ and available phosphorus $(<10$ ppm, Bray 1) (Adu, 1995; Benneh et al., 1990). A large proportion of the soils are also shallow with iron and magnesium concretions (Adu, 1969).

Soil fertility management in Ghana is sub-optimal thus affecting yields. Fertilizer nutrient application in Ghana is approximately $8 \mathrm{~kg}$ per ha while depletion rates, which are among the highest in Africa, range from about 40 to 60 $\mathrm{kg}$ of nitrogen $(\mathrm{N})$, phosphorus $(\mathrm{P})$, and potassium $(\mathrm{K})$ per hectare per year. Estimates show negative nutrient balance for all crops in Ghana(FAO, 2005). The escalating rates of soil nutrient mining are a serious threat to sustainability of agriculture and poverty reduction in Ghana. There are also inefficiencies and bottlenecks in fertilizer distribution networks which limit access, and add to the cost of fertilizer in farming communities. Agro-input marketing is rudimentary and farmer-based organizations are also weak and therefore unable to acquire credit, fertilizer and other inputs in bulk to reduce cost (FAO, 2005). These are likely to affect decisions on the use of fertilizers and other agro-inputs in the country.

Integrated Soil Fertility Management (ISFM) is the approach advocated by Alliance for a Green Revolution in Africa (AGRA) to improve the soil fertility and soil health status of African soils. AGRA has demonstrated its commitment to improving the health of the soils in northern Ghana by funding the Soil Health Project 005 which is being implemented by CSIR-Savanna Agricultural Research Institute between 2009 and 2013. Most studies on soil fertility management focused on quantifying the socio-economic, institutional and production factors which influence adoption and fertilizer use intensity among smallholder farmers (Akpani, Udoh, \& Nkanta, 2012; Ariga, Kibaara, \& Nyoro, 2009; Tchale \& Wobst, 2004; Waithaka, Thornton, Shepherd, \& Ndiwa, 2005). According to MSU (1998), fertilizer use intensity is constrained by both external and internal factors which include access to credit, access to input and output markets, access to complementary inputs which have "thin" markets like manure and lack of appropriate knowledge base, erratic rainfall pattern, transport cost, access to irrigation and storage facilities. In addition to these factors, this study investigated other important factors within the context of the AGRA Soil Health Project that have the potential to influence fertilizer adoption among smallholder farmers in northern Ghana.

There are myriads of models ranging from binary to multinomial that have been proposed to study the adoption behaviours of farmers as well as the fundamental determinants of technology adoption. Normally, the econometric specification depends largely on the objective of the study and the type of data available (Shiferawa, Kebede, \& You, 2008). Studies on adoption of technology employ the logit and probit models where the dependent variable is dichotomous whereas Tobit model measures the intensity of use of a technology (Adesina \& Zinnah, 1993; Kristjanson et al., 2005; Maddala, 1983; Shiyani et al., 2002; Tobin, 1958) given the restrictive assumption that the probability of adoption and use intensity are jointly determined.

This study examined this assumption and employed the Double Hurdle Model (DHM) as developed by Cragg (1971) to empirically determine fertilizer adoption and use intensity in northern Ghana. The model employed in this study is appropriate since fertilizer adoption and intensity of use are two distinctive choices. The DHM is a parametric generalization of the Tobit model in which two separate stochastic processes determine the decision to adopt fertilizer technology and the intensity of fertilizer use. The model assumes that farm household heads make two consecutive decisions with respect to adoption and intensity of use of fertilizer. The first hurdle involves the fertilizer adoption equation estimated by employing the probit model whereas the second hurdle involves an outcome equation, which uses a truncated model to determine the extent of optimum use of fertilizer. According to Coady (1995) and Croppenstedt et al. (2003), the DHM has been used in modeling constrained adoption and intensity of use of new technologies mainly because it accounts for the existence of a significant number of farmers with positive desired demand for modern inputs but are too constrained to adopt them.

\subsection{Concept and Justification of the AGRA Soil Health Project}

The Soil Health Project (SHP) aims at improving smallholder farmer productivity, through increasing access to locally appropriate soil nutrients and promoting ISFM. The objectives of the programme were to (1) create in five years, physical and financial access to appropriate fertilizers for around 4.1million African smallholder farmers in an efficient, equitable and sustainable manner (2) create in five years, access to appropriate ISFM knowledge, agronomic practice and technology packages, for around 4.1million African smallholder farmers and 
(3) create a policy environment for investment in fertilizer and ISFM in African countries.

In a bid to translate the above objectives into implementable actions, three sub-programs were established, which constitute major strategic levers of the SHP. These include:

(i) Research and Extension: It seeks to facilitate the adoption of improved ISFM technology packages that promote the use of both mineral and organic fertilizers and conservation agriculture production practices. It also provided funding to soil scientists to test various ISFM technology options to identify and promote those that enhance smallholder farmer productivity.

(ii) Fertilizer Value Chain Development: Fertilizer sub-program aims at catalyzing local production of fertilizer through support to local companies that are providing appropriate blends using local phosphate rocks.

(iii) Capacity building in the form of training: The aim is to maintain a supply of soil scientists to provide research and extension support to farmers. Soil laboratory technicians were also trained to improve the quality of laboratory management and outputs. Training was also provided to extension staffs who worked directly with farmers.

\section{Method}

\subsection{Study Area}

The study covered smallholder farmers in northern Ghana consisting of Northern, Upper East and Upper West Regions. The three regions share borders with Republic of Togo to the east, Ivory Coast to the west and Burkina Faso to the north. Within the country, the northern Ghana is bordered by Volta Region on the south east and Brong-Ahafo Region on the south west (Figure 1). Geographically, the three regions are between longitude $8^{\circ} 46^{\prime} 01.88^{\prime \prime} \mathrm{N}$ and $10^{\circ} 58^{\prime} 34^{\prime \prime} \mathrm{N}$ and latitude $2^{\circ} 45^{\prime} 45.40^{\prime \prime} \mathrm{W}$ and $0^{\circ} 32^{\prime} 59.95^{\prime \prime} \mathrm{E}$ and cover a total land area of $97,666 \mathrm{~km}^{2}$ with an estimated population of 3,317,478. The vegetation is a typical Guinea Savannah type; which is characterized by drought-resistant grasses and trees. Northern Ghana plays an important role in agriculture and is normally referred to as the grain basket of the country. More than 80 percent of the inhabitants of northern Ghana are full-time farmers (MoFA/SRID, 2011). Most smallholder farmers in these regions have benefited from a lot of development projects aimed at increasing productivity and improving livelihoods. However, poverty is rated high in the region.

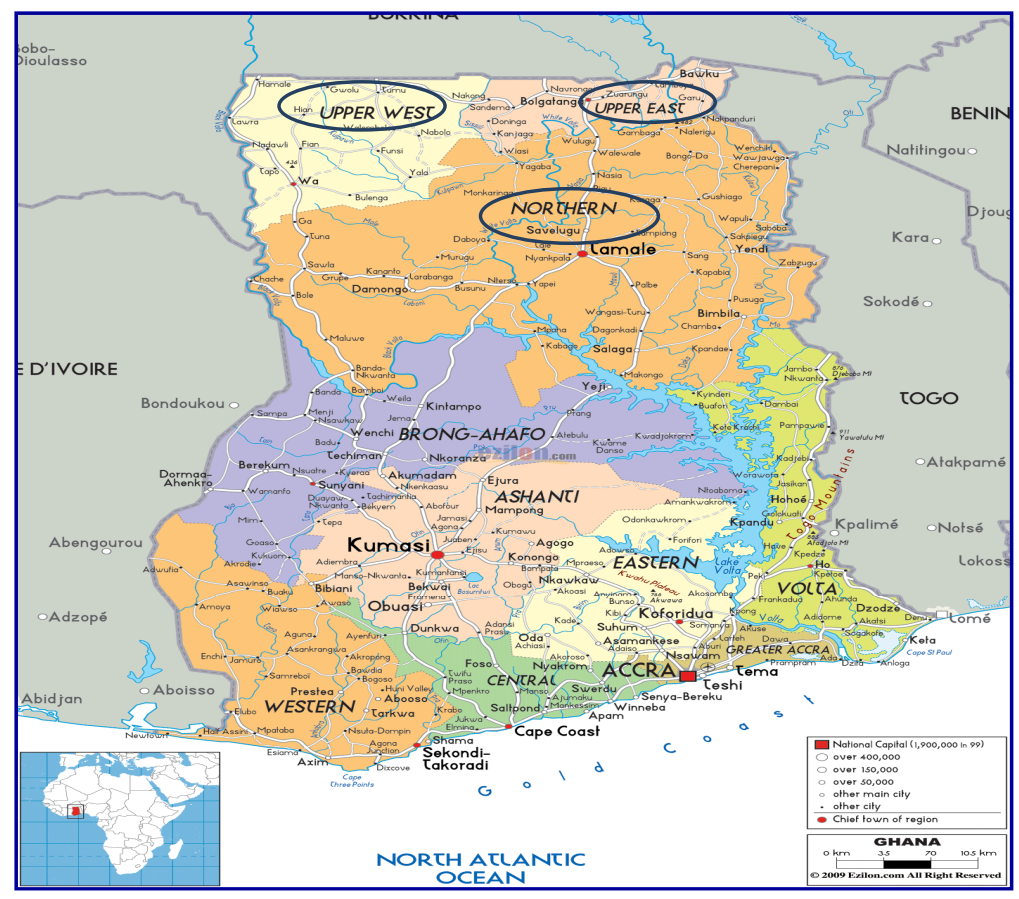

Figure 1. Administrative map of Ghana

\subsection{Data and Sampling Technique}

The study was conducted between October and November, 2012. The basic information for the analysis was 
obtained from primary data collected with the aid of a structured questionnaire. In addition to the survey, key informants interviews and focus group discussion were conducted to augment the household survey.

A total of 330 smallholder farmers were systematically and randomly selected and interviewed. The sample frame for the study was the AGRA Soil Health Project 005 (AGRA SHP005) targeted districts in the three regions. The sampling process combined purposive, stratified and random procedures in 3 stages. At the first stage, 11 districts (five from Northern Region; three from Upper East Region; and three from Upper West region) were purposively selected to include project districts. Within each district, the list of beneficiary communities were stratified into three groups namely project community, non-project communities within $5 \mathrm{~km}$ away from a project community, and non-project communities located $5 \mathrm{~km}$ away from a project communitys. Two communities were selected randomly from each group making a total of 6 communities per district. At the community level five households were further randomly selected from a list of farm households. In all, 330 farmers from 66 communities drawn from 11 districts were involved in the study (Table 1).

Table 1. Sampling frame

\begin{tabular}{lccc}
\hline Region & Districts & Communities (6 per district) & Household (5 per community) \\
\hline Northern & 5 & 30 & 150 \\
Upper East & 3 & 18 & 90 \\
Upper West & 3 & 18 & 90 \\
\hline Total & 11 & 66 & 330 \\
\hline
\end{tabular}

\subsection{Estimation of Fertilizer Adoption and Use Intensity}

\subsubsection{Introduction}

The Double Hurdle model was used for the analysis with the assumption that the adoption decision and the intensity use were independently determined. In order to justify the use of the Double Hurdle model, a restriction test was carried out where the log likelihood values were obtained from a separate estimation of Tobit, Probit and Truncated regression models. Based on the values obtained, the following likelihood ratio statistic was computed using the formula below:

$$
\lambda=2\left(L L_{\text {Probit }}+L L_{\text {Truncreg }}-L L_{\text {Tobit }}\right)
$$

The test statistic has a chi-square distribution with degrees of freedom equal to the number of independent variables (including the intercept). The Tobit model is rejected in favour of the Double Hurdle model if $\lambda$ exceeds the appropriate chi-square critical value (Burke, 2009).

\subsubsection{Double Hurdle Model}

\section{First Hurdle - Fertilizer Technology Adoption}

The individual's adoption decision of fertilizer technology is dichotomous, involving two mutually exclusive alternatives. The individual either adopts or does not. The framework for such analysis has its root in the threshold theory of decision making in which a reaction occurs only after the strength of a stimulus increases beyond the individual's reaction threshold (Hill \& Kau, 1981). This implies that every individual when faced with a choice has a reaction threshold influenced by several factors.

The present study adopted the Probit regression model to quantify the factors influencing the probability of fertilizer technology adoption among smallholder farmers in northern Ghana. The fact that the dependent variable is a dichotomous justifies the use of a binary model (i.e. Probit model). The Probit model was ideal because of its ability to constrain the utility value of the decision to adopt variable to lie within zero and one, and its ability to resolve the problem of heteroscedasticity (Asante et al., 2011). Accordingly, the dependent variable, adoption of fertilizer technology $(\mathrm{Y})$ assumes only two values: one if the farmer adopts fertilizer technology and zero if a farmer does not adopt.

According to Akinola and Owombo (2012), given the assumption of normality, the probability that $y_{i}^{*}$ is less than or equal to $y_{i}$ can be computed from the normal cumulative normal distribution as follows:

$$
P_{i}=P\left(Y=\frac{1}{X}\right)
$$




$$
\begin{gathered}
P_{i}=P\left(y_{i}^{*}<y_{i}\right) \\
P_{i}=P\left(Z_{i}<\beta_{0}+\beta_{j} X_{i j}\right)=F\left(Y_{i}\right) \\
P\left(Y=\frac{1}{X}\right)=F(X B)=\frac{1}{\sqrt{2 \pi}} \int_{-\infty}^{X B} e^{\frac{-(X B)^{2}}{2}} d x \\
X=\left(1, x_{1 i}, x_{2 i}, \ldots \ldots, x_{k i}\right) \\
\beta^{\prime}=\left(\beta_{0}, \beta_{1}, \ldots \ldots \ldots \ldots, \beta_{k}\right)
\end{gathered}
$$

Where $y_{i}^{*}$ is the critical or threshold level of the index, such that if $y_{i}$ exceeds $y_{i}^{*}$, the farmer adopts fertilizer technology, otherwise the farmer does not. $P\left(Y=\frac{1}{X}\right)$ is taken as the probability that the farmer adopts fertilizer technology given the values of explanatory variables $\mathrm{X}$, and where $Z_{i}$ is a random variable normally distributed with mean zero and unit variance, $Z_{i} \sim N\left(0, \sigma^{2}\right)$. The relative effect of each explanatory variable on the likelihood that a farmer will adopt fertilizer technology is specified as follows:

$$
\frac{\partial P_{i}}{\partial X_{i j}}=\beta_{i j} * f\left(Z_{i}\right)
$$

Where $f\left(Z_{i}\right)$ is the inverse of the cumulative normal function and $\beta_{i j}$ are the estimated parameters. The elasticity of the predicted probability is then computed as:

$$
\frac{\partial P_{i}}{\partial X_{i j}}=\beta_{i j} * f\left(Z_{i}\right) * \frac{\bar{x}}{P_{i}}
$$

The empirical model employed to determine the fertilizer adoption is given as:

$$
\begin{gathered}
Y_{i}=\beta_{0}+\beta_{1} \text { Age }+\beta_{2} \text { Gend }+\beta_{3} \text { Mar }+\beta_{4} \text { Edu }+\beta_{5} \text { Fmexp }+\beta_{6} \text { Natv }+\beta_{7} \text { Income }+\beta_{8} \text { Area }+ \\
\beta_{9} \text { Fertsta }+\beta_{10} \text { Crdt }+\beta_{11} \text { Lvstk }+\beta_{12} \text { FmOrg }+\beta_{13} \text { DstAg }+\beta_{14} \text { Acsinpt }+\beta_{15} \text { DstInp }+\mu_{i}
\end{gathered}
$$

Where, $\beta_{0}$ is the constant term $\beta_{1}, \beta_{2}, \beta_{3}, \ldots \ldots \ldots, \beta_{15}$ are the parameters of the respective explanatory variables in the model, and $\mu_{i}$ is the error term.

Second Hurdle - Fertilizer Use Intensity

The second level of the analysis involved the determination of the factors that influences fertilizer use intensity. The second hurdle model uses the truncated regression model to determine the extent of fertilizer use intensity. Observations on positive and greater than the optimum fertilizer use intensity are only used in the analysis. The intensity of fertilizer use $\left(Y_{i}\right)$ is specified as:

$$
Y_{i}=\frac{\text { Quantity of Fertilizer Use }(\mathrm{Kg})}{\text { Total Area of Land }(\mathrm{Ha})}
$$

The decision to intensify fertilizer use is modeled as a regression truncated below the average fertilizer use intensity as expressed below:

$$
\begin{gathered}
Y_{i}^{*}=X_{i} \beta+\mu_{i}, \mu_{i} \sim N\left(0, \sigma^{2}\right) \\
Y_{i}=\left\{\begin{array}{l}
Y_{i}^{*} \text { if } Y_{i}^{*}>0 \text { and } d_{i}=1 \\
0 \text { if } Y_{i}^{*} \leq Y_{0} \text { and } d_{i} \leq 1
\end{array}\right.
\end{gathered}
$$

Where $Y_{i}$ is the fertilizer use intensity which depends on the latent variable $Y_{i}^{*}$ being greater than zero and conditional to the decision to adopt fertilizer $\left(d_{i}\right), X_{i}$ is the vector of explanatory variables hypothesized to influence fertilizer use intensity, $Y_{0}$ is the threshold fertilizer use intensity in the study area.

The empirical model employed to determine the fertilizer use intensity is given as:

$$
\begin{gathered}
Y_{i}=\beta_{0}+\beta_{1} \text { Age }+\beta_{2} \text { Gend }+\beta_{3} \text { Mar }+\beta_{4} \text { Edu }+\beta_{5} \text { Fmexp }+\beta_{6} \text { Nat }+\beta_{7} \text { Income }+\beta_{8} \text { Fertsta } \\
+\beta_{9} \text { Lvstk }+\beta_{10} \text { FmOrg }+\beta_{11} \text { DstAgr }+\beta_{12} \text { Acsinpt }+\beta_{13} \text { DstInp }+\beta_{14} \text { Occu }+\beta_{15} \text { DstMkt } \\
+\beta_{16} \text { IncGend }+\beta_{17} \text { IncHcat }+\mu_{i}
\end{gathered}
$$

where, $\beta_{0}$ is the constant term $\beta_{1}, \beta_{2}, \beta_{3}, \ldots \ldots, \beta_{22}$ are the parameters of the respective explanatory variables in the model, and $\mu_{i}$ is the error term. The estimates for these parameters were obtained using the STATA SE software version 11. Appendix 1 shows the host of explanatory variables that are potentially expected to explain variation in adoption and fertilizer use intensity and their a priori expectations. 


\subsection{Description of Explanatory Variables}

Age is expected to influence fertilizer use intensity positively (Adesina \& Forson, 1995; Chinu \& Tsujii, 2004; Fufu et al., 2006; Gbetibouo, 2009; Olwande et al., 2009). Older household head are more risk averse and are assess the attributes of a technology than younger household heads (Ayamga, 2006). Resource constraint may also be a limiting factor among younger household heads in terms of fertilizer use intensity though they are more dynamic with regards to adoption of innovations (Enete \& Igbokwe, 2009). Gender (Gend) of household head affects adoption and fertilizer use intensity positively. Females are normally occupied with domestic activities and are also resource (financial and human) and these negatively impact on both adoption decision and the extent of fertilizer use. It is expected that households head that are married will have a higher probability of fertilizer adoption and use intensity. Married household heads (Mar) are normally assisted by their spouses in production, processing and marketing decision-making. Marriage also increases a farmer's concern for household welfare and food security which is therefore likely to have a positive effect on their decision to adopt and increase fertilizer use intensity (Nnadi \& Akwiwu, 2008).

Education (Edu) is expected to have a positive effect on both fertilizer adoption and intensity of use. It enables an individual to make independent choices and to act on the basis of the decision, as well as increase the tendency to co-operate with other people. (Enete \& Igbokwe, 2009; Ofori, 1973; Southworth \& Johnston, 1967; Schultz, 1945). It is also possible that education could increase the chances of the household head earning non-farm income which could reduce the household dependency on agriculture and thus the intensity of fertilizer use. Experienced (Fmexp) farmers are more likely to adopt fertilizer technology. The opposite holds true for hertilizer use intensity. Some agricultural extension programmes use experienced farmers in the demonstration of new technologies to increase adoption. Agricultural activities are more risky especially where a new technology is introduced which negatively affects the extent of use of that technology. Nativity of household head determines access to communal resource like land and irrigation facility for farming and access to these facilities enhance adoption and fertilizer use intensity negatively (Amanze et al., 2010; Olawale, Arega, \& Arega, 2009; Coady, 1995)

Participation in agricultural development projects is expected to influence farmers' fertilizer adoption and fertilizer use intensity either positively or negatively. Agricultural projects usually providecrucial information to enhance the productive skills of farmers. It is also possible that a farmer may participate in a developmental project for other technical supports thus impacting negatively on fertilizer adoption and use intensity. Household heads that are engaged in farming as their main occupation are more likely to adopt any fertilizer technology. Income (Inc) of household head is positively related to both adoption and fertilizer use intensity. High transaction cost in terms of transportation normally limits the extent of fertilizer use. Income earning farm households are able to overcome the financial constraint with respect to technology adoption and purchase. Farmers' perception of soil fertility status (Fertsta) affects the adoption and extent of use both positively and negatively. Farm size is expected to positively influence fertilizer adoption. A higher farm size may normally be accompanied with a corresponding increase in complementary technologies ceteris paribus. Agricultural credit (Crdt) is one of the major institutional factors limiting technology uptake by most smallholder farmers. Household heads with access to credit are more likely to adopt fertilizer technology. Intensity of fertilizer use is high especially among household heads with access to input credit. Livestock ownership status (Lvstk) is used as a proxy for availability of household resource endowment (Heyi \& Mberengwa, 2012). Farmers who are resource endowed will have a higher propensity of adoption and intensity of fertilizer use. Household head membership of an association/group (FmOrg) increases access to information which is important to production and marketing decisions (Olwande, 2010). Most farmer groups engage in group marketing, bulk purchasing of inputs and credit provision for its members. It is therefore expected that household head membership of association/group will positively affect adoption as well as intensity of fertilizer use.

Household heads with access to inputs (Acsinpt) are more likely to adopt fertilizer but may not necessarily determine the extent of use of fertilizer. Distance to input market (DstInp) is one of the major limiting factors for inputs purchase as it imposes a high transaction cost to producers. The adoption and fertilizer use intensity decreases with an increase in the distance to the nearest input market (Amanze \& Eze, 2010; Zhou, Yang, Mosler, \& Abbaspor, 2010; Olayide, Arega, \& Ikpi, 2009). Agriculture officers play a crucial role in the demonstration and dissemination of agricultural technology therefore distance to an agricultural office (DstAgr) impacts negatively on the adoption and extent of fertilizer use due to the limitation in terms of information access.

The interactive term, income and participation in agricultural development project (Inc*PatAgra) is posited to influence the intensity of fertilizer use positively. Fertilizer use intensity is positively affected by the interactive term, age and agricultural development project (Age*PatAgra). Participation in agricultural development 
projectby older farm household heads will enhance their information access and as well as productive skills to guide their production activities. Finally, income and gender of household head (Inc*Gend) is expected to influence both adoption and intensity of fertilizer use both positively and negatively. Male-headed household who earn income is more likely to adopt and intensify fertilizer use relative to the female headed household who earn income. Females are generally constraint in terms of resources and will use income to enhance household food and nutritional requirement.

\section{Results and Discussion}

\subsection{Determinants of Fertilizer Adoption and Use Intensity}

The double hurdle was best suited for the data based on the restriction test as specified in Equation (1). The Tobit model was rejected in favour of the Double-hurdle model because the computed lambda from the likelihood ratios exceeded the critical chi2 value. The probit model was used to estimate the parameters of the determinants of fertilizer technology adoption by smallholder farmers in northern Ghana. The significant Wald chi-square value of 100.90 indicates that the explanatory variables jointly influence the farmers' decision to adopt fertilizer technology (Table 2). Adoption of fertilizer technology was significantly determined by age, nativity, farm size occupational status, access to credit, and distance to agricultural office. Farm size was the most influential determinant of adoption of fertilizer technology in northern Ghana.

The extent of fertilizer use was significantly determined by income of household head, membership of farmer association, distance to agricultural office, access to input shop, income earning household that do not participate in agricultural development project and income earning male headed household. Access to input shop was the most influential determinant of fertilizer use intensity both statistically and numerically. The significant Wald chi-square value of 70.59 indicates that the explanatory variables jointly influence the fertilizer use intensity (Table 2).

The probability of fertilizer technology adoption was influenced negatively by age of household head. The result implied that older household heads were less likely to adopt fertilizer. A unit increase in the age of the household head decreases the probability of fertilizer adoption by 0.005 . Normally younger household heads are more dynamic and innovative in terms of technology adoption (Enete \& Igbokwe, 2009). The opposite is true for fertilizer use intensity.

Nativity influenced the adoption of fertilizer technology negatively. The result indicated that native household heads are less likely to adopt the fertilizer technology relative to the non-native household heads. The probability of fertilizer technology adoption among native household heads was lower than non-native household heads by 0.229. Nativity guarantees access to communal agricultural resources as well as security of the resources. Non-native household heads usually have informal agreement with land owners with regard to the share of farm produce after harvest. The demand on these household heads influence their decision to adopt and use of technology (improved seed, fertilizer and good agricultural practices) that guarantee higher yields.

Contrary to expectation, income of households head had a negative effect on fertilizer use intensity. A unit increase in household income led to a $0.254 \mathrm{~kg} / \mathrm{ha}$ decrease in fertilizer use intensity. The result contradicted the findings of Feder et al. (1985) and Freeman and Omiti (2003). They observed that wealthier farmers are capable of taking risks due to their additional resources to fall on in case of any unforeseen circumstances. Investment of financial resource in interest earning assets and high demand on food and other social responsibilities are likely to explain the result of low fertilizer use with increase in income.

Area under cultivation was negatively related to fertilizer adoption. The implication of the result was that as farm size increases, farmers were more likely not to adopt fertilizer. The marginal effect showed that a unit increase in the area under cultivation reduced the probability of fertilizer adoption by 0.355 . The result confirmed the findings by Olayide (2009) and Coady (1995). Adoption of fertilizer in northern Ghana is low especially among smallholder farmers largely due to financial constraint. The present finding explicate the reasons for advocacy by agricultural projects for farmers to own relatively manageable plots of farm lands.

Credit access was negatively associated with probability of fertilizer adoption. Household heads with access to credit are less likely to adopt fertilizer technology. The probability of adoption of fertilizer among household heads without credit access was 0.139 more than those with credit access. Access to farm credit is one of the major challenges facing smallholder farmers in the study area. It is possible that farmers with credit will be more likely to divert part of their financial resource to other productive ventures that yield profit. Farm credit may also be used to pay for land preparation, purchase of other farm inputs and support for household food requirement. The result implies that farmers in the study area must be supported with input credit rather than cash credit. 
Fertilizer use intensity was positively influenced by membership of association. The fertilizer use intensity among household heads that belong to farmer association was $37.12 \mathrm{~kg} / \mathrm{ha}$ more than household heads that do not belong to farmer organization. Farmer association served as platform for accessing and dissemination of information and technology. Most agricultural development projects in northern Ghana (such as Northern Rural Growth Programme, Millennium Challenge Account Programme, Rice Sector Support Project, AGRA Soil Health Project, Fertilizer Subsidy Programme, Agricultural Value Chain Mentorship Project, AfricaRISING Project, etc.) target farmer groups to enhance and build their business and technical capacity respectively and subsequently support them with input credit and market opportunities. Farmers belonging to associations and cooperative have easy access to fertilizer technology, fertilizer coupon, and credit which has a positive effect on fertilizer use. The outcome of the study implies commitment on both governmnent and non-governmental organizations to work towards the sustainability of farmer associations.

Distance to agricultural office had a positive outcome on fertilizer adoption and intensity of use. The result indicated that increase in the distance to agricultural office was likely to increase adoption and fertilizer use intensity. A unit increase in the distance to the agricultural office leads to a 0.008 and $1.98 \mathrm{~kg} / \mathrm{ha}$ increases in fertilizer adoption and intensity of use respectively. The agricultural office serves as proxy for access to agricultural extension agents. Access to extension agents will increase farmers' awareness and information on the importance of technology adoption (Akpan et al., 2012). However, the result contradicts literature as distance serves as a barrier for technology adoption. It is also likely that farmers depend more on neighbouring farmers for useful information on fertilizer use relative to most of the agricultural extension agents that are not accessible to farmers.

Furthermore, household heads that have access to input shops were not likely to intensify fertilizer use. The intensity of fertilizer use among household heads with access to input shop is $64.29 \mathrm{~kg} / \mathrm{ha}$ lower than household heads that do not have access to input shops. It can be deduced from the result that access to input shop is not a guarantee for increase in intensity of fertilizer use. Studies by Akpan et al. (2012), Amanze et al. (2010), Olawale et al. (2009), Olayide et al. (2009), and Wanyama et al. (2009), have suggested distance to the sale of fertilizer as influential determinant of fertilizer use intensity rather than access to input shop. However, the present study has shown that access to input shop may not necessarily translate to fertilizer use intensity by smallholder farmers in northern Ghana. Access to input shop must be complemented by willingness to pay and education.

Income earning male-headed household were more likely to intensify fertilizer use. For income earning male-headed households, the extent of fertilizer use was $0.026 \mathrm{~kg} / \mathrm{ha}$ more than income earning female-headed household. Income earning male headed household have access to resources such as productive land and credit facilities relative to their female counterparts. Wanyama et al. (2010) found a similar result though the component of the income was not captured in the analysis. Inaccessibility to production credit limits female-headed household with respect to fertilizer use.

Finally, the intensity of fertilizer use by income earning households that participated in agricultural development project was lower than non-participant income earning household heads. For household heads that earn income and participate in agricultural development project, the extent of fertilizer use is $0.022 \mathrm{~kg}$ /ha lower than income earning non-participant household heads. The relatively lower use of fertilizer among these farmers may be attributed to high dependency on household heads coupled with attitudinal behavior which requires continuous sensitization and education. The AGRA SHP005 was implemented to promote the use of ISFM practices among farmers in Northern Ghana to boost productivity. Myriads of approaches have been used to reach out to the farmers. Notably among these interventions include demonstrations, Farmer Based Organization (FBO) capacity building and facilitation of input credit to farmers. Farmers normally have wide-ranging intentions for participating in any agricultural development projects rather than aligning themselves to the objectives of the project. In situations where project is not able to meet the expectation of these farmers, they tend to abandon the project concept and follow their old practices of farming. The project may be contributing towards the adoption of fertilizer technology but not intensity of fertilizer use. The AGRA SHP005 must be sustained to increase the level of farmers' awareness on fertilizer use. 
Table 2. Double hurdle estimates of adoption and fertilizer use intensity

\begin{tabular}{|c|c|c|c|c|}
\hline \multirow[b]{2}{*}{ Variable } & \multicolumn{2}{|c|}{ 1st Hurdle (Probit) } & \multicolumn{2}{|c|}{ 2nd Hurdle (Truncated) } \\
\hline & $\begin{array}{l}\text { Marginal } \\
\text { Effect }\end{array}$ & $\begin{array}{l}\text { Robust Std. } \\
\text { Error }\end{array}$ & $\begin{array}{l}\text { Marginal } \\
\text { Effect }\end{array}$ & $\begin{array}{l}\text { Robust Std. } \\
\text { Error }\end{array}$ \\
\hline Gender of household head & -0.05042 & 0.45971 & 30.8741 & 54.9118 \\
\hline Age of household head & $-0.00525 * *$ & 0.00564 & -0.3936 & 0.6299 \\
\hline Marital status of household head & 0.02951 & 0.36064 & -70.4662 & 45.6083 \\
\hline Educational status of household head & 0.09868 & 0.24456 & 15.3738 & 24.2752 \\
\hline Years of Farming experience & 0.00054 & 0.00209 & 0.0213 & 0.0461 \\
\hline Nativity of household heads & $-0.22993^{*}$ & 0.41617 & -54.4339 & 65.6421 \\
\hline Income level of household head & 0.00000 & 0.00000 & $-0.2539 * * *$ & 0.0072 \\
\hline Farm Size & $-0.35519 * * *$ & 0.10259 & - & - \\
\hline Perception of soil fertility & -0.09954 & 0.19551 & -3.9396 & 21.2442 \\
\hline Access to credit & $-0.13927 * *$ & 0.18812 & - & - \\
\hline Ownership of livestock & -0.04386 & 0.24523 & -17.2508 & 14.9231 \\
\hline Membership of farmer organization & 0.02468 & 0.19749 & $37.1189^{*}$ & 21.8678 \\
\hline Distance to agricultural office & $0.00816^{*}$ & 0.01197 & $1.9865 * *$ & 0.9444 \\
\hline Access to input shop & -0.08342 & 0.23439 & $-64.2922 * * *$ & 23.5930 \\
\hline Distance to input shop & -0.00449 & 0.02143 & -1.0316 & 1.5039 \\
\hline Occupational Status & - & - & -41.3162 & 32.6127 \\
\hline Distance to market & - & - & 0.0789 & 0.0777 \\
\hline Income*Gender & - & - & $0.0257 * * *$ & 0.0072 \\
\hline Income*Participation in project & - & - & $-0.0219 * * *$ & 0.0067 \\
\hline No. of Observation & 319 & & 311 & \\
\hline Wald Chi2 (15) & 100.9 & & 70.59 & \\
\hline Prob $>$ Chi2 & 0.0000 & & 0.0000 & \\
\hline Pseudo R-Squared & 0.3927 & & - & \\
\hline Log Pseudolikelihood & -125.18171 & & -1903.4343 & \\
\hline
\end{tabular}

Source: Regression Estimation from Author's Household Survey Data (2012).

$* * * \mathrm{p}<0.01, * * \mathrm{p}<0.05$ and $* \mathrm{p}<0.10$.

\section{Conclusion}

Soil fertility management is a critical issue in northern Ghana and has attracted the attention of several programmes that promotes ISFM practices among smallholder farmers. The study revealed that adoption of fertilizer technology was significantly determined by age, nativity, farm size, access to credit, and distance to agricultural office. Fertilizer use intensity was significantly determined by income of household head, membership of farmer association, distance to agricultural office, access to input shop, income earning household that do not participate in agricultural development project and income earning male headed household. Participation in agricultural development project does not necessarily lead to increase in adoption and fertilizer use intensity. Distance to agricultural office also plays a major role in fertilizer adoption and use intensity in the study area.

Based on the findings of the study, it is recommended that agricultural development programmes should target FBOs as well as support them with technical training to enhance their technology uptake. Secondly, government policy should aim at supporting farmers with input credit to increase the use of fertilizer as well as sustaining the fertilizer subsidy programme. Improvement in infrastructure such as road is crucial in influencing the use of 
fertilizer. Finally, the AGRA Soil Health Project 005should intensively engage the agricultural extension agents in training on fertilizer use to ensure that quality information is disseminated to farmers.

\section{Acknowledgement}

The authors of this paper wish to express their profound gratitude to Alliance for a Green Revolution in Africa (AGRA) for the financial support for generation of the data through the AGRA Soil Health Project 005. The administrative support of the host institution, CSIR-SARI is acknowledged. Finally, all the technicians who worked tirelessly to collect the data are also appreciated.

\section{References}

Adesina, A. A., \& Baidu-Forson, J. (1995). Farmers' Perceptions and Adoption of New Agricultural Technology Evidence from Analysis in Burkina Faso and Guinea, West Africa. Agricultural Economics, 13, 1-9. http://dx.doi.org/10.1016/0169-5150(95)01142-8

Adesina, A. A., \& Zinnah, M. M. (1993). Technology Characteristics, Farmers' Perceptions and Adoption Decisions: A Tobit Model Application in Sierra Leone. Agric. Econ., 9, 297-311. http://dx.doi.org/10.1016/0169-5150(93)90019-9

Adu, S. V. (1969). Soils of the Navrongo-Bawku area, Upper Region of Ghana. Memoir No. 5. Soil Research Institute. Kumasi.

Adu, S. V. (1995). Soils of the Nasia basin. Memoir No. 6. Soil Research Institute, Kumasi.

Akinola, A., \& Owombo, P. (2012). Economic Analysis of Adoption of Mulching Technology in Yam Production in Osun State, Nigeria. Journal of Agriculture and Forestry, 2(1), 1-6. http://dx.doi.org/10.5923/j.ijaf.20120201.01

Akpan, S. B., Nkanta, V. S., \& Essien, U. A. (2012). A Double-Hurdle Model of Fertilizer Adoption and Optimum Use among Farmers in Southern Nigeria. TROPICULTURA, 30(4), 249-253. http://www.tropicultura.org/text/v30n4/249.pdf

Akpani, S. B., Udoh, E. J., \& Nkanta, V. S. (2012). Factors Influencing Fertilizer Use Intensity among Smallholder Crop Farmers in Abak Agricultural Zone in Akwalbom State, Nigeria. Journal of Biology, Agriculture and Healthcare., 2(1). http://www.iiste.org/Journals/index.php/JBAH/article/view/1127

Amanze, B., Eze, C., \& Eze, V. (2010). Factors Influencing the Use of Fertilizer in Arable Crop Production among Smallholder Farmers in Owerri Agricultural Zone of Imo State. Academia Arena, 2(6), 90-96.

Ariga, J., Jayne, T. S., Kibaara, B., \& Nyoro, J. K. (2009). Trends and Patterns in Fertilizer Use by Smallholder Farmers in Kenya, 1997-2007. Tegemeo Institute of Agricultural Policy and Development. Retrieved from http://fsg.afre.msu.edu/aamp/seminar_2/seminar_3_kenya.pdf

Asante, B. O, Afari-Sefa V., \& Sarpong, D. B (2011). Determinants of Small-Scale Farmers' Decision to Join Farmer Based Organizations in Ghana. Afr. J. Agric. Res., 6(10), 2273-2279. Retrieved from http://ugspace.ug.edu.gh/handle/123456789/2572?show=full

Ayamga, M. (2006). Factors influencing the decision to Participate in Microcredit Programmes: An illustration for Northern Ghana. Ghana J. Dev. Stud., 3(2), 57-65. Retrieved from http://www.ajol.info/index.php/gjds/article/view/35043

Benneh, G., Agyepong, G. T., \& Allotey, J. A. (1990). Land degradation in Ghana. Commonwealth Secretariat, London and University of Ghana. Legon. Retrieved from http://searchworks.stanford.edu/view/2406253

Burke, W. J. (2009). Fitting and interpreting Cragg's tobit alternative using Stata. The Stata Journal, 9(4), 584-592. Retrieved from http://ageconsearch.umn.edu/bitstream/143014/2/sjart_st0179.pdf

Chamberlin, J. (2007). Defining Smallholder Agriculture in Ghana: Who are Smallholders, What do they do and how are they linked with markets: Ghana Strategy Support Program (GSSP). Background Paper No. GSSP 0006. http://www.ifpri.org/sites/default/files/publications/gsspwp06.pdf

Chinu, J. N., \& Tsujii, H. (2004). Determinant of Farmer's Decision to Adopt or not to Adopt Inorganic Fertilizer in Savanna of Northern Nigeria. Nutr. Cyc. Agroecosyst., 70, 293-301.

Coady, D. P. (1995). An Empirical Analysis of Fertilizer use in Pakistan. Economica, 62, 213-234. http://dx.doi.org/10.2307/2554904

Cragg, J. G. (1971). Some Statistical Models for Limited Dependent Variables with Applications to the Demand for Durable Goods. Econometrica, 39, 829-844. http://dx.doi.org/10.2307/1909582 
Croppenstedt, A., Demeke, M., \& Meschi, M. M. (2003). Technology Adoption in the Presence of Constraints: The Case of Fertilizer Demand in Ethiopia. Rev. Dev. Econ., 7(1), 58-70. http://dx.doi.org/10.1111/1467-9361.00175

Enete A. A., \& Igbokwe, E. M. (2009). Cassava Market Participation Decision of Household in Africa. Tropicultura, 27(3), 129-136.

FAO. (2005). Fertilizer Use by Crop in Ghana, Land and Plant Nutrition Management Service, Land and Water Development Division, Food and Agriculture Organization of the United Nations, Rome. Retrieved from http://ftp.fao.org/agl/agll/docs/fertuseghana.pdf

Feder, G., Just, R. E., \& Zilberman, D. (1985). Adoption of Agricultural Innovations in Developing Countries: A Survey. Economic Development and Cultural Change, 33(2), 255-298. http://dx.doi.org/10.1086/451461

Freeman, H. A., \& Omiti, J. M. (2003). Fertilizer use in semi-arid area of Kenya: analysis of smallholder farmers' adoption behavior under liberalized markets. Nutrient Cycling in Agroecosystems, 66, 23-31. http://dx.doi.org/10.1023/A:1023355011400

Fufu, B., \& Hassan, R. M. (2006). Determinants of Fertilizer Use in Maize in Eastern Ethiopia. A weighted Endogenous Sampling Analysis of the Extent and Intensity of Adoption. Agrekon, 45(1), 38-49.

Ghana Statistical Service, GSS. (2008). Ghana Living Standards Survey Report of the Fifth Round (GLSS 5), Accra, Ghana, p. 131. http://www.statsghana.gov.gh/docfiles/glss5_report.pdf

Heyi, D. D., \& Mberengwa, I. (2012). Determinants of Farmers' Land Management Practices: The Case of Tole District, South West Shewa Zone, Oromia National Regional State, Ethiopia. Journal of Sustainable Development in Africa, 14(1). $\quad$ Retrieved from http://www.jsd-africa.com/Jsda/Vol14No1-Spring2012A/PDF/Determinants\%20of\%20Farmers\%20Land\%2 0Management\%20Practices.Heyi\%20and\%20Mberengwa.pdf

Hill, L., \& Kau, P. (1981). Analysis of Purchasing Decision with Multivariate Probit. Amer. J. Agric. Econ., 53(5), 882-883.

Kristjanson, P., Okike, I., Tarawali, S., Singh, B. B., \& Manyong, V. M. (2005). Farmers' Perceptions of Benefits and Factors Affecting the Adoption of Improved Dual-Purpose Cowpea in the Dry Savannas of Nigeria. Agric. Econ., 32, 195-210. http://dx.doi.org/10.1111/j.0169-5150.2005.00338.x

Maddala, G. S. (1983). Limited Dependent and Qualitative Variables in Econometrics. Cambridge University Press, London. Retrieved from http://www2.econ.iastate.edu/classes/econ533/Herriges/Misc/SylS08.pdf

Ministry of Food and Agriculture, MoFA. (2010). Agriculture in Ghana: Facts and Figures (p. 53), Accra, Ghana.

MSU. (1998). Incentives for Fertilizer Use in sub-Saharan Africa: A Review of Empirical Evidence on Fertilizer Response and Profitability. In International Development Working Paper No. 71 Department of Agricultural Economics, Michigan State University (MSU), East Lansing, MI. Retrieved from http://ideas.repec.org/p/ags/midiwp/54677.html

Nnadi, F. N., \& Akwiwu, C. D. (2008). Determinants of Youths' Participation in Rural Agriculture in Imo State, Nigeria. Journal of Applied Sciences, 8(2), 328-333. http://dx.doi.org/10.3923/jas.2008.328.333

Ofori, I. M. (1973). Factors of Agricultural Growth in West Africa. ISSER, University of Ghana, Legon, Accra, Ghana.

Olawale O., Arega D., \& Arega I. (2009). Determinants of fertilizer use in Northern Nigeria. Pakistan Journal of social Sciences, 6, 2, 91-98.

Olayide, O. E., Arega, D., \& Ikpi, A. (2009). Determinants of fertilizer use in Northern Nigeria. Pakistan Journal of Biology, Agriculture and Healthcare.

Olwande, J., \& Mathenge, M. (2010). Market Participation among the Poor Rural Households in Kenya. Tegemeo Institute of Agricultural Policy and Development. Retrieved from http://ageconsearch.umn.edu/bitstream/126711/1/Olwande.pdf

Schultz, Theodore W. (1945). Agriculture in an unstable Economy. New York: McGraw-Hill Book Company Inc. Retrieved from http://www.questia.com/library/1287243/agriculture-in-an-unstable-economy

Shiferawa, B. A., Kebede, T. A., \& You, L. (2008). Technology Adoption under Seed Access Constraints and The Economic Impacts of Improved Pigeonpea Varieties In Tanzania. Agricultural Economics, 39, 309-323.

Shiyani, R. L., Joshi, P. K., Asokan, M., \& Bantilan, M. C. S. (2002). Adoption of Improved Chickpea Varieties: 
KRIBHCO Experience in Tribal Region of Gujarat, India. Agric. Econ., 27(1), 33-39. http://dx.doi.org/10.1111/j.1574-0862.2002.tb00102.x

Southworth, H. M., \& Johnston, B. F. (1967). Agricultural Development and Economic Growth. U.K: Cornell University Press.

Statistical Research and Information Department, SRID, Ministry of Food and Agriculture (2012). National Crop production estimates 2011. Accra, Ghana.

Tobin, J. (1958). Estimation of Relationships for Limited Dependent Variables. Econometrica, 26, 24-36. http://dx.doi.org/10.2307/1907382

Waithaka, M. W., Thornton, P. K., Shepherd, K. D., \& Ndiwa, N. N. (2005). Factors Affecting the Use of Fertilizers and Manure by Smallholders: The Case of Vihiga, Western Kenya. NutrCyclAgroecosyst, 78, 211-224. http://dx.doi.org/10.1007/s10705-006-9087-x

Wanyama, J. M., Mose, L. O., Rono, S. C., \& Masinde, A. A. O. (2009). Determinants of fertilizer use and soil conservation practices in maize based cropping system in Trans Nzoia District, Kenya. A publication of Kenya Agricultural Research Institute, Kitale.

Appendix 1. List of explanatory variables

\begin{tabular}{llc}
\hline Variable & Description & A priori \\
\hline Age & Age of household head in years & $+/-$ \\
Gender of household head (Gend) & 1 if male and 0 other wise & + \\
Marital status (Mar) & 1 if married and 0 otherwise & + \\
Education (Educ) & 1 if educated and 0 otherwise & + \\
Years of farming experience (Fmexp) & Number of years & $+/-$ \\
Participation in AGRA SHP (PatAgra) & 1 if participates and 0 otherwise & + - \\
Occupational status (Occ) & 1 if farmer and 0 otherwise & + \\
Income (Inc) & Amount in GH & $+/-$ \\
Perception on soil fertility status (Fertsta) & 1 if soil is rich and 0 otherwise \\
Access to credit (Credit) & 1 if household receive credit and 0 otherwise & + \\
Livestock ownership (Lvstk) & 1 if owns livestock and 0 otherwise & + \\
Membership of farmer association (FmOrg) & 1 if member of farmer association and 0 otherwise & + \\
Distance to market (Dstmkt) & Distance in Km from house to market & - \\
Distance to agricultural office (DstAgr) & Distance in Km from house to agricultural office & - \\
Distance to agricultural shop (DstAgr) & Distance in Km from house to input shop & - \\
Access to input (Acsinpt) & 1 if household have access and 0 otherwise & $+/-$ \\
Nativity (Nat) & 1 if native and 0 otherwise & $+/-$ \\
Interactive Term & & \\
Income \& Participation in project (IncPatAgra) & Income*Participation in AGRA SHP \\
Age \& Participation in project (AgePatAgra) & Age*Participation in AGRA SHP \\
Income and Gender (IncGend) & Income * Gender & + \\
\hline
\end{tabular}


Appendix 2. Tobit regression estimates of fertilizer use intensity

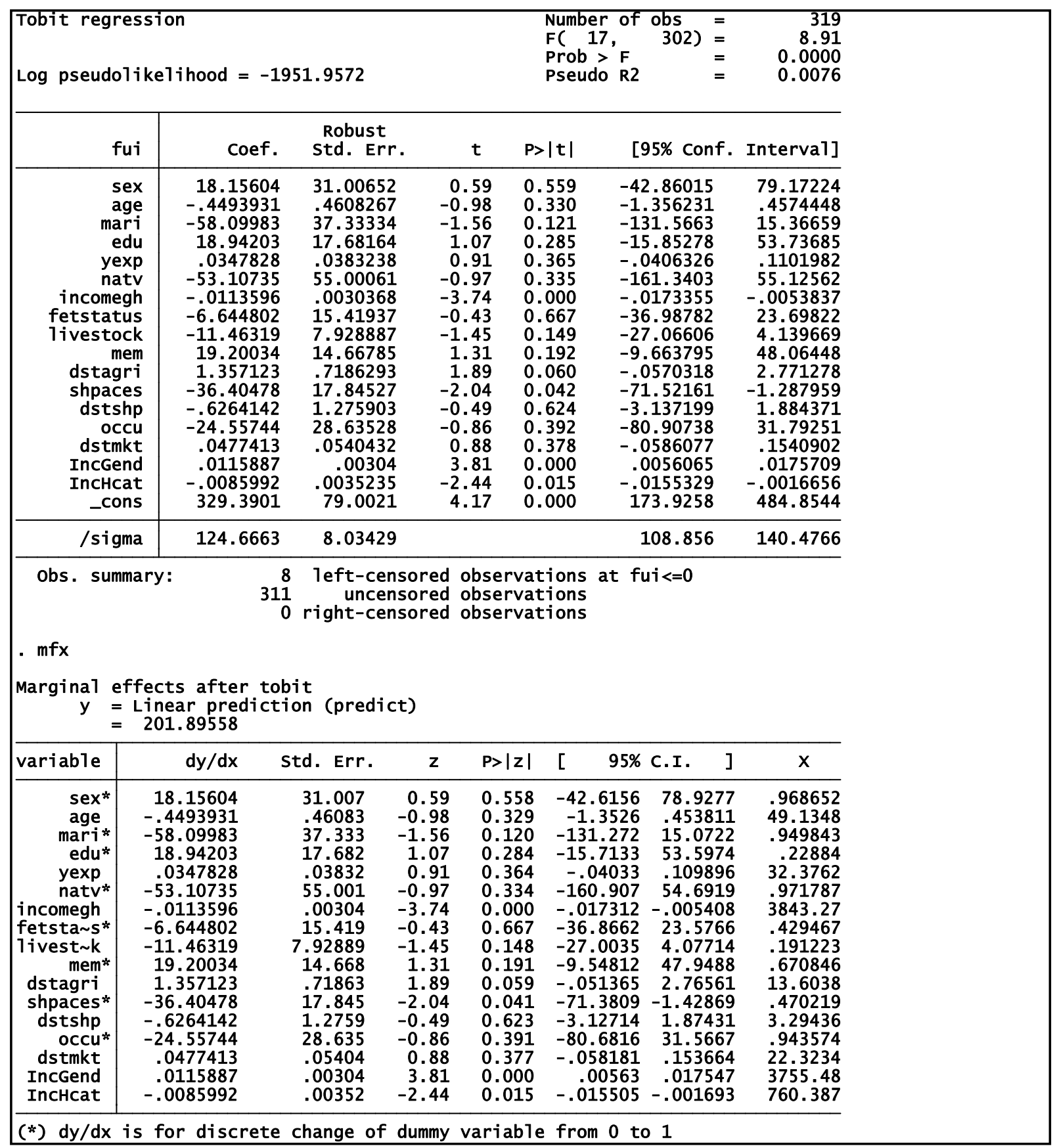

\section{Copyrights}

Copyright for this article is retained by the author(s), with first publication rights granted to the journal.

This is an open-access article distributed under the terms and conditions of the Creative Commons Attribution license (http://creativecommons.org/licenses/by/3.0/). 